\title{
The Importance of Literature and Cultural Transfer - Redefining Minority and Migrant Cultures ${ }^{1}$
}

\author{
Petra Broomans
}

In many works on nationality, ethnicity and identity by scholars such as Benedict Anderson, Miroslav Hroch and Ernest Gellner we learn that the expression of our identity is connected with language and the place we are born. In our lives we are continuously taking positions, as individuals and as part of a family or a social group. Over time people have migrated or were forced to migrate; others have become part of new nation-states while remaining in the same place. Over time people have lost their mother tongue, learned a new one and/or regained the old one. This is a process that can be observed among minorities, migrants, refugees, people in exile and expats. These processes are not bound to one single area but can be regarded as a global phenomenon. While this volume focuses on such minority and migrant groups in northwestern Europe, their experiences, positions and strategies can be compared with minority and migrant groups in other parts of the world, and the reflections here might also offer a point of departure for theoretical thinking on this topic in other regions.

The contributions in this volume discuss the many positions and decisions of minorities and migrants in northwestern Europe over the last 200 years. These groups have created new identities, learned new languages, or attempted to preserve and reconstruct lost languages. In this introduction, I will firstly reconsider the concepts of 'minority' and 'migrant' cultures and literatures in the past and the present, locating the contributions to this volume within the context of a variety of perspectives, such as nationalism studies, literary history and cultural transfer. Secondly, I will deal with how literature and cultural transfer have been used as

1 I am grateful for the comments and suggestions made by co-editor Janke Klok and by Jeanette den Toonder, my co-coordinator of the theme group Beyond Horizons in Cultural Transfer (Research Centre Arts in Society, University of Groningen). 
important tools for expressing identity, as well as how writers within small groups acted on the institutional level. Finally, the third part will present the eight papers in this volume. As will become apparent, both this introduction and the contributions point towards a new topic for further study - the differences between the various categories of minorities and the importance of literature and cultural transfer for minorities as well as for migrant groups, whether or not they are in the diaspora, writing in new languages or creating new identities.

\section{Positioning the question}

How should we define minorities and migrants? Should the concept of 'minority' literatures and cultures be distinguished from 'migrant' literatures and cultures? In addition to these questions, there are also various types of small language communities. 'Small' does not necessarily mean having less influence, as the Czech historian Miroslav Hroch argues in his seminal study, Social Preconditions of National Revival in Europe. A Comparative Analysis of Patriotic Groups among the Smaller European Nations (1985). ${ }^{2}$ A small group may also gain power due to historical developments. Moreover, sometimes a group of people speaking a 'major' language lives in an area or a state where it has a minority position. Thus, a small language community with a certain language, culture and ethnicity may have various positions. Over time, states, institutions and organisations may take different approaches and have different attitudes towards both minority and migrant groups. In the following, I will position minority and migrant groups in the context of historical studies on nationalism before examining the institutional dimension. I will then move towards a definition of migrant and minority groups.

\section{The historical dimension}

Hroch, mentioned above, is one of the scholars who have discussed the rise of small groups with nationalistic tendencies in Europe in the nineteenth and beginning of the twentieth century and - relevant to our topic - how the gathering of literary texts was used in this process. He formulated

2 Originally written in German with the title Die Vorkämpfer der nationalen Bewegung bei den kleinen Völkern Europas, published in 1968. 
three main phases in the development of national movements: Phase A. A period of scholarly interest, or as Bruno de Wever put it aptly, 'a small group of passionate intellectuals shows interest in the culture of the small nation'; Phase B. A period of patriotic agitation, illustrated by the founding of institutions such as publishing houses, journals and associations; and Phase $\mathrm{C}$. The rise of a mass national movement. The working class also becomes involved and starts to strive for political independence or autonomy.

Hroch calls this movement a 'national transformation process', a process that he links to three stages of social transformation: the first concerns the battle against the old regime, entailing civil and social revolutions and the rise of industrial capitalism; a second stage sees the breakthrough of industrial capitalism and the rise of a working class; and the third stage involves economic rescaling and increasing mass communication. The precise synergy between the national transformation process and the social transformation stages allows for four types of national movements: 1 . an integrated movement, 2 . a late movement, 3. an insurrection movement, and 4. a disintegrated movement. According to Hroch, not every national movement results in the formation of a state. A disintegrated movement, for example, does not reach Phase C. Examples of such movements are the Flemish movement in Belgium ${ }^{4}$ and the Frisian minority in the Netherlands. ${ }^{5}$

Hroch does not give a specific definition of a small community or minority, but uses the notions of 'Patriotic Group' and 'Small Nation'. It is evident that Hroch takes the 'nation' as a point of departure and thus we need to explore his definition of nation before we can define what a minority is. In the following description of the 'nation', Hroch speaks explicitly of a 'large social group':

3 Bruno de Wever, 'From Language to Nationality. The Case of the Dutch-speaking Belgians in the Nineteenth Century', in: Petra Broomans, Goffe Jensma, Hans Vandevoorde and Maarten Van Ginderachter, eds., The Beloved Mothertongue. Ethnolinguistic Nationalism in Small Nations: Inventories and Reflections (Louvain, 2008), p. 53. De Wever gives a useful and clear summary of Hroch's description.

4 See De Wever, 'From Language to Nationality’, pp. 49-61.

5 Goffe Jensma, 'Minorities and Kinships. The Case of Ethnolinguistic Nationalism in Friesland', in: Petra Broomans, Goffe Jensma, Hans Vandevoorde and Maarten Van Ginderachter, eds., The Beloved Mothertongue. Ethnolinguistic Nationalism in Small Nations: Inventories and Reflections (Leuven, 2008), pp. 63-78. 
Now the nation is not, of course, an eternal category, but was the product of a long and complicated process of historical development in Europe. For our purposes, let us define it at the outset as a large social group integrated not by one but by a combination of several kinds of objective relationships (economic, political, linguistic, cultural, religious, geographical, historical), and their subjective reflection in collective consciousness. Many of these ties could be mutually substitutable - some playing a particularly important role in one nation-building process, and no more than a subsidiary part in others. But among them, three stand out as irreplaceable: (1) a 'memory' of some common past, treated as a 'destiny' of the group - or at least of its core constituents; (2) a density of linguistic or cultural ties enabling a higher degree of social communication within the group than beyond it; (3) a conception of the equality of all members of the group organized as a civil society. ${ }^{6}$

We can observe that Hroch remarks that the 'nation' is a product of a historical process and not something that unites people from the beginning. While the notions of 'the self' and 'the other' are only implicit in his description, they are discernable and can be linked to the ideas of Édouard Glissant, who is more explicit, stating that the nation is the 'root' that excludes 'the other', whereas humankind is rooted in migration and nomadism. ${ }^{7}$ Both Hroch and Glissant consider the 'nation' to be a product of historical development; however, Glissant has a more negative conception of the 'nation'. I will discuss Glissant's perspective further below. Nevertheless, Hroch's three 'irreplaceable' ties, collective memory, linguistic and cultural cohesion, and the notion of the equality of all citizens, which are the conditions for nation-building, are elements that, in my opinion, can be transferred to small social and other groups.

In his work, Hroch also gives a historical and teleological dimension to the phenomenon of small groups and the phases they undergo within a larger political context. His thinking is endorsed by many scholars within the field of history and nationalism studies, including Eric Hobsbawm. In

6 Miroslav Hroch, 'From National Movement to the Fully-formed Nation: The Nation-building Process in Europe', in: Gopal Balakrishnan, ed., Mapping the Nation (New York/London, 1996), pp. 78-97. See especially, p. 79.

7 Édouard Glissant, Poetics of Relation (Ann Arbor, 1997). 
his study, Nations and Nationalism since 1780. Programme, Myth, Reality (1990), Hobsbawm even regards Hroch's work as opening a 'new era in the analysis of the composition of national liberation movements'. ${ }^{8}$

Hroch is one of the many scholars who have reflected upon the question: What is a nation?, or as Ernest Renan put it in his classic lecture, 'Qu'est-ce qu'une nation?' (1882). Ernest Gellner and Benedict Anderson have also addressed this question. Gellner's study Nations and Nationalism (1983) is regarded as one of the seminal scholarly works on nationalism, while Benedict Anderson presents a compelling idea of the nation as a construction in Imagined Communities. Reflections on the Origin and Spread of Nationalism, published in the same year as Gellner's book (1983). For Anderson, the nation is 'an imagined community':

It is imagined because the members of even the smallest nation will never know most of their fellow-members, meet them, or even hear of them, yet in the minds of each lives the image of their communion. Renan referred to this imagining in his suavely backhanded way when he wrote that 'Or l'essence d'une nation est que tons les individus aient beaucoup de choses en commun, et aussi que tous aient oublié bien des choses.'

It goes without saying that this mechanism, imagining the nation, could also be applied to small nations and minority groups.

Hroch further elaborated his theories on small nations and nationalism in the European context in his study Das Europa der Nationen. Die modern Nationsbildung im europäischen Vergleich (2005). Hroch starts with with a state of research and discusses the problem of defining the nation. Some characteristics of the 'nation' that Hroch describes are of relevance to my argument here..$^{10}$ Most importantly, the nation is linked to its history, ethnicity, language identity, the beginnings of modernity, literacy and the printing press, the role of conflicts of interest of different kinds, such

8 Eric Hobsbawm, Nations and Nationalism since 1780. Programme, Myth, Reality (Cambridge, 1990), p. 4.

9 Benedict Anderson, Imagined Communities: Reflections on the Origin and Spread of Nationalism (London, 1983), p. 49.

10 Miroslav Hroch, Das Europa der Nationen. Die moderne Nationsbildung im europäischen Vergleich (Göttingen, 2005), p. 38. 
as inequality, social status, etc., and the question of cultural and socialpsychological cohesion. Furthermore, Hroch discusses various types of nations: nation-states as unifying states and nation-states that split from supranational larger states. ${ }^{11}$ Most small nations developed in the latter manner. Another type that can be linked to small language communities is that of not ruling ethnic groups that began national movements in the nineteenth century. Hroch sees this kind of nation-building and these types of nation-states, often already developed in mediaeval times, as the two most important types of small nations in Europe..$^{12}$ Another central issue that Hroch describes is the importance of nations being regarded as such, with or without a history. ${ }^{13}$ The importance of language, culture and education in the construction of a nation is also dealt with.

The gathering of literary texts is also used in the mobilisation of a people. Hroch mentions several genres that are of relevance: journalistic texts, educational texts, folklore and folk poetry, as well as translations and adaptations of literary texts from more developed literatures. ${ }^{14}$ The production of novels usually occurs later in the process, although short stories might be published in journals and newspapers. According to Hroch, drama is also a genre that develops early in the process. ${ }^{15}$ With respect to the development of academic literature, this often depends on the number of people who receive a higher education in the young nation and how many of them participate in the major institutions of the state. ${ }^{16}$

The construction of a common history and the creation of a common culture and language also occur within minority groups. In my opinion, the process that occurred in the nineteenth century as described by Hroch can be observed in more recent modern history in new minority groups that appeared after the Second World War, for example the Tornedalians in Sweden.

Hroch, Das Europa der Nationen, p. 41.

12 Hroch, Das Europa der Nationen, p. 42.

13 Hroch, Das Europa der Nationen, p. 145.

14 Hroch, Das Europa der Nationen, p. 185.

15 Ibidem.

16 Hroch, Das Europa der Nationen, p. 186. 


\section{The institutional dimension}

In addition to the historical dimension, there is an institutional dimension to any understanding of minority and migrant groups. In particular, we should look at how European political and other institutions defined minority and migrant groups after the Second World War.

The European Charter for Regional or Minority Languages uses the following definition:

A. 'regional or minority languages' means languages that are:

i. traditionally used within a given territory of a State by nationals of that State who form a group numerically smaller than the rest of the State's population

ii. different from the official language(s) of that State

iii. do not include either dialects of the official language(s) of the State or the languages of migrants

B. 'territory in which the regional or minority language is used' means the geographical area in which the said language is the mode of expression of a number of people justifying the adoption of the various protective and promotional measures provided for in this Charter

C. 'non-territorial languages' means languages used by nationals of the State which differ from the language or languages used by the rest of the State's population but which, although traditionally used within the territory of the State, cannot be identified with a particular area thereof. ${ }^{17}$

Some observations can be made here. Firstly, the point of departure is the 'State', thus we are dealing with a political border that is presented as relatively fixed. Secondly, the notion of 'territory' is fundamental both for regional (hence the notion of territory) and minority languages in a given area and for 'non-territorial languages' that cannot be linked to a specific area. A description of the difference between a regional or a minority language and the dialect of a part of the majority is not given, nor is a reason why the languages of migrant groups are not included. Is this because, over time, migrant groups have become minorities? As one example, the Moluccan

17 http://languagecharter.coe.int/docs/Translations/authentic_2c.pdf http://languagecharter.coe.int/byLanguage.htm (accessed October 15 2015). 
minority in the Netherlands can be mentioned here. This group was brought to the Netherlands by the Dutch government in 1951 because they had served in the Koninklijk Nederlandsch-Indisch Leger (KNIL, the Royal Netherlands East Indies Army), which was dissolved after Indonesian independence. Their position in the new Republic of Indonesia was complicated, with the Christian Moluccans, especially, regarded with suspicion by their compatriots and the new Indonesian government. Not only were many of them former KNIL soldiers, but they had also proclaimed the Republic of the South Moluccans (Republik Maluku Selatan, RMS) on the island of Ambon in April 1950. As a result of the political circumstances, this group of approximately 3,800 exsoldiers was evacuated to the Netherlands in 1951 with their families - a total of 12,582 people. ${ }^{18}$ The Dutch government promised the Moluccans that their stay in the Netherlands would be temporary and that they would be able to return home after a short period, but for several reasons this never occurred, thus the Moluccans became a minority in Dutch society.

The European Charter for Regional or Minority Languages was adopted by the Committee of Ministers of the Council of Europe in 1992 and became effective in 1998. In 2015, the Charter was ratified by 25 states. ${ }^{19}$ The language of the Moluccans is not listed in the Charter. This is also the case for Eurasians in the Netherlands, descendants of Dutch colonial men and Indonesian women, another group that migrated to the Netherlands after the Second World War.

In another definition, which can be found on the Eurominority website for Stateless Nations and Minority Peoples in Europe - which also has the motto 'Think Europe differently' - the description of the differences is more specific. ${ }^{20}$ This definition includes 'national, cultural and linguistic minorities, native peoples, ethnic groups, areas with strong identity and autonomist, independantist (sic) or separatist tendencies'. The website allows the visitor to search for a minority on the basis of several positions: within a state, thus the notion of territory is used here as well; by type of conflict; and by type of claim, here political circumstances are taken as a frame of reference. In both of the latter two categories, minorities not facing conflicts (e.g. the Frisians) de backpay-kwestie 1945-2005 (Amsterdam, 2005), p. 195. (accessed October 15 2015).

20 See: http://www.eurominority.eu/version/eng/ (accessed October 15 2015). 
or making claims (e.g. the Åland Islands) are also listed. In relation to our discussion of how to define a minority, the types listed are of interest:

- Stateless Nation/People (accomplished, with political institutions or a high degree of autonomy)

- Stateless Nation/People (mature and aware of its cultural specificities)

- Stateless Nation/People (revival of the cultural identity)

- Stateless Nation/People (in danger of dissolution of the cultural specificity)

- Native people (specific community, sharing its area with other communities)

- National minority (community of an eponymic State)

- Nomadic or scattered people ${ }^{21}$

This overview has several features that remind us of Hroch. It also reflects a hierarchy. At the top is the nation or people that has obtained autonomy and has built institutions. One could compare this with Phase C of Hroch's division, but without a political state. The second category can be compared with Phase B, when more people are mobilised, after the first Phase, A, in which a small group of intellectuals, writers and artists start to define/ redefine the cultural identity of the group by gathering or constructing/ reconstructing a literary canon, among other activities. The third category, peoples whose cultural specificity is in danger, could be compared with the communities whose language is in danger, such as those mapped by UNESCO in the UNESCO Atlas of the World's Languages in Danger. ${ }^{22}$ Native peoples are in a category of their own, the only indigenous people in Europe, are the Sámi in Scandinavia and on the Kola peninsula in Russia. ${ }^{23}$ After the native peoples, national minorities are listed. The notion of an 'eponymic state' is used here. Examples are the Danes (Denmark) in the north of Germany and the Germans in Denmark. The lowest in the hierarchy are the nomadic or scattered peoples, with no institutions or any apparent awareness of their own cultural specificity. The latter, it should be noted, is not always the case, as in several countries, Sweden for example, the Roma are aware of their

21 http://www.eurominority.eu/version/eng/minority-type.asp (accessed October 15 2015).

22 http://www.unesco.org/culture/ (accessed October 15 2015).

23 The Inuit, an indigenous people from Greenland, forms a minority in Denmark.

Greenland is an autonomous part of the Kingdom of Denmark. 
cultural identity. Writers, artists and activists such as the sisters Rosa Taikon (1926) and Katarina Taikon-Langhammer (1932-1995) in Sweden could to some extent be compared with the cultural actors of Hroch's Phase A. ${ }^{24}$

The description on the Eurominority website also overlaps to a certain extent with the definition of the Charter. In the former, the state is also the point of departure, but the notion of 'native' is added and the state of awareness and the existence or lack of institutions is included. This implies a political contextualisation from the perspective of the minorities, whereas the Charter implies a fixed European border system, with states involved, and it has an institutional approach. While EU institutions do not include migrants in their political documents, it is obvious when speaking of minorities that one should include migrants in the discussion.

\section{Towards a definition of migrants and minorities}

In her introduction to the seminal book, Litteraturens gränsland. Invandraroch minoritetslitteratur $i$ nordiskt perspektiv (2002), the editor, Satu Gröndahl, makes a distinction between 'invandrar' (migrant) literature and minority literature. She proposes the following categories of ethnic groups: migrant groups, more specifically the new migrants after 1945; and historical or territorial minority groups. ${ }^{25}$ According to Gröndahl, migrant groups are in a phase of cultural encounter with the majority group, while historical groups are in a phase of negotiating their identity and position over and against the major group. Gröndahl also depicts migrant groups as minority groups. ${ }^{26}$ In the Nordic region, minor language groups, whether or not they are migrants or belong to historical or territorial minority groups, are fewer in number than what is regarded as the major language community. However, either kind of group may hold power, as did the white minority, the Afrikaners, in South Africa until the 1990s. Historically speaking, one could call the Swedish-speaking minority in Finland a dominant group that lost its status only after Finland became a grand duchy of Russia in 1809.

24 See: http://www.varromskahistoria.se/en/what-happened-sweden/activism (accessed October 15 2015) and Lowen Mohtadi, Den dag jag blir fri. En bok om Katarina Taikon (Stockholm, 2012).

Gröndahl, ed., Litteraturens gränsland. Invandrar-och minoritetslitteratur $i$ nordiskt perspektiv (Uppsala, 2002), p. 13.

26 Ibidem. 
Furthermore, Gröndahl regards another category of migrant literature, exile literature, as part of a global literary community, or as a 'partial' culture of Sweden. She also mentions the Kurds, a community that has been scattered over many countries and that has a strong cultural community in Sweden. The same can be said of Estonians who fled to Sweden and Canada. ${ }^{27}$ In some cases, state borders are no longer important. However, when a migrant author starts to write in the language of the majority, the category of 'exile literature' might no longer apply. In my opinion, one could characterise this as language assimilation, with the literary works no longer exploring themes and/or motives that deal with the position of the ethnic group. However, if the ethnic theme is still apparent, such works might be regarded as undertaking the cultural transfer of the migrant/ minority literature into the major literature, bringing about an awareness of the position of the minority community. In this case, the negotiation strategy, as Gröndahl calls it, can begin.

\section{Multiculturality, interculturality and transculturality}

Along with the study of migrants, movements such as nomadism and migration have also been studied and discussed. This development demands new approaches and perspectives that go beyond nationalism studies. One such approach has been proposed by Wolfgang Welsch, who developed the concept of 'transculturality', arguing against Herder's 'traditional concept of single cultures' and the modern concepts of 'interculturality' and 'multiculturality' ${ }^{28}$ Is this new concept of relevance here? According to Welsch, both from an intercultural and multicultural perspective, culture is still regarded as folk-bound. One might correlate such a notion of a single and folk-bound culture with the notion of the nation as a singular entity: 'It still proceeds from a conception of cultures as islands or spheres'. ${ }^{29}$ Interculturality, however, reflects another understanding of cultures and how they interact with each other. For Welsch, cultures are never isolated or in simple conflict with each other but are in fact

27 Gröndahl, pp. 17-18.

28 Wolfgang Welsch, 'Transculturality - the Puzzling Form of Cultures Today', in: Mike Featherstone and Scott Lash, eds., Spaces of Culture: City, Nation, World (London, 1999), pp. 194-213.

29 Welsch, 'Transculturality', p. 3. 
entangled. Furthermore, Welsch argues that in modern cultures, both globalisation and local affiliation can be handled within the framework of transculturality: 'Transcultural people combine both'. ${ }^{30}$ While this idea of 'transculturality' is of interest and we will return to it below, Welsch does not take into consideration the importance of language for migrants and minorities, even in modern times, with the terms 'language' and 'speech' not mentioned at all.

\section{Homelands, migration, nomadism}

Up to this point, I have not mentioned the place of origin of migrants. For territorial and historical minorities, the homeland is a given, even when it is situated in a different state and there are different major languages used by the minority apart from its own language. The Swedish scholar Harald Runblom discusses the concept of homeland and the relationship between migrants and their homelands, both the old and the new, making some interesting observations. ${ }^{31}$ Here, I will also discuss Charles Westin's contribution to the volume edited by Runblom in an attempt to define 'homeland' and the concepts of migration, migrant and minority groups ${ }^{32}$

Runblom states that it is impossible to give a fixed definition of homeland, as it depends on the position of the migrant and how they perceive their homeland. Thus, various aspects have to be dealt with. It can have connotations relating to 'fatherland' (i.e. related to territory and later to the nation-state) or 'motherland' (i.e. blood relationship). ${ }^{33}$ Although Runblom does not mention it, one could compare the word 'nation' with the Latin nasci, to be born. ${ }^{34}$ The word refers to the place where a child is born

30 Welsch, 'Transculturality', p. 10.

31 Harald Runblom, 'Introduction. Homeland As Imagination and Reality', in: Harald Runblom, ed., Migrants and the Homeland. Images, Symbols, and Realities, Uppsala Multiethnic Papers 44 (Uppsala, 2000), pp. 9-30.

32 Charles Westin, 'Migration, Time, and Space', in: Harald Runblom, ed., Migrants and the Homeland. Images, Symbols, and Realities, Uppsala Multiethnic Papers 44 (Uppsala, 2000), pp. 33-42.

33 Runblom, 'Introduction', p. 11.

34 Flemming Lundgreen-Nielsen, 'Danskhed - hvorfor og hvorledes?', in: Flemming Lundgreen-Nielsen, ed., På sporet af dansk identitet. Syv humanistiske forskere fortceller historien om hvordan vi gennem tiderne er blevet os bevidste som dansk (Copenhagen, 1992), p. 7. 
and thus intrinsically connects this place to motherhood..$^{35}$ This is the place of youth and where the child is raised but it does not need to be positioned in a state. Thus, the notion of a 'fatherland' might be considered as a symbol for the state - a political entity - while 'motherland' could be connected to the mother tongue and the ethnic group to which one belongs.

States change over time, and how the old and the new homelands are remembered and perceived depends on the position of the migrant, their phase of life, or why they migrated, for example for economic or political reasons. Runblom argues that a multigenerational perspective is needed here. First generation migrants have different memories and perceptions of the homeland to second or third generation migrants. The question of whether or not a migrant can integrate into the new homeland and whether or not the group itself has established strong associations and institutions in the new homeland is also important. The strength of the migrant group also depends to a great extent on the strength of their sense of homeland. Successful migrant groups manage to contribute their own elements to the canon of the new homeland and thus come to be included in the new homeland ideology. ${ }^{36}$

Migration is thus a two-way process, migrants have images of their homeland and carry these images with them to the new homeland, and they also create images of the new homeland after migrating. ${ }^{37}$ Migration includes movement. Migrants travel by train, boat, plane, etc. to the new homeland and also cross borders. However, there are also migrants who move within a state, for example Italians moving from the south to the

35 See also Petra Broomans, 'I fadershuset. Om kön och nationell identitet i nordisk litteraturhistorieskrivning', in: Malan Marnersdóttir and Jens Cramer, eds., Nordisk litteratur og mentalitet. Foredrag fra den 22. Studiekongres i International Association for Scandinavian Studies (IASS) arrangeret af Føroyamálsdeid, Fróskaparsetur Føroya, Færøernes Universitet 3-9 August 1998. Annales Societatis Scientiarum Færoensis. Supplementum XXV, 2000, p. 41.

36 Runblom, 'Introduction', p. 17.

37 Here imagology, as it is developed by Joep Leerssen, could be applied as well. Texts on travelling from one place (territory) to another or travelling in other countries (fictional or not) are excellent resources for studying the images that cultures have of each other. See, for example, Manfred Beller and Joep Leerssen, eds., Imagology: The Cultural Construction and Literary Representation of National Characters-A Critical Survey. Series: Studia Imagologica, Vol. 13; Series editors: Hugo Dyserinck and Joep Leerssen (Amsterdam/New York, 2007). 
north of Italy, or Sámi from the north of Scandinavia to the cities in the south. While Westin states that international migration and the crossing of borders means crossing linguistic and cultural borders, this can also be said for migrants within state borders. For example, the Sámi left their rural territory for an urban environment and also crossed cultural and, in some cases, linguistic boundaries.

Thus, whether international or internal, the movement associated with migration has both spatial and temporal dimensions. Westin defines migration as a movement that is definitive, 'unidirectional', and that takes place over a 'significant length of time' and a 'significant stretch of space, across significant boundaries, or away from home. The national or state boundary is the most significant boundary to be crossed, the boundary of the homeland' ${ }^{38}$ Thus, after the physical crossing there is a temporal crossing. After arrival and settlement, time is required for psychological adjustment to the new situation, to the new culture, learning to communicate in the new language, acquiring a repertoire of social skills that are appropriate to the new environment, and a basic understanding of how things operate in the new context so as to provide for oneself and for one's family. ${ }^{39}$

As we have observed, the notion of the state is the point of departure for scholars such as Hroch and in the institutional definitions discussed above. In the studies on migration, the state is also a strong factor. In contrast, Welsch's concept of transculturality, as shown above, challenges the notion of a single and folk-bound culture that correlates with the nation or state. Another scholar who challenges the notion of a single culture and 'state thinking' is Édouard Glissant, briefly mentioned above. Inspired by Gilles Deleuze and Félix Guattari, Glissant discusses nomadism and migration, arguing that a strong belief in the state has to be abandoned. Rather than thinking of identity in terms of taking root, Deleuze and Guattari propose the metaphor of the rhizome, 'an enmeshed root system', designating a network in the ground or in the air. In contrast to the unique or singular root which tends to kill everything around it, the notion of the 'rhizome' propagates the idea of a multiple, non-hierarchical rootedness that challenges the 'totalitarian root'. Glissant calls this rhizomatic thought the 'Poetics of Relation', in which every identity is 'extended through the relationship with the other'. ${ }^{40}$

38 Westin, 'Migration, Time, and Space', p. 41.

39 Westin, 'Migration, Time, and Space', p. 38.

40 Édouard Glissant, Poetics of Relation (Ann Arbor, 1997), p. 11. 
Glissant also refers to Kant, who opposed the settled way of life, truth and society to nomads, scepticism and anarchy. ${ }^{41}$ Glissant describes different forms of nomadism: circular nomadism and invading nomadism. The latter is more aggressive than the former. ${ }^{42}$ On the other hand Glissant also defines arrowlike nomadism, a variant of invading nomadism. As an example he mentions the Visigoths, who gradually settled down in a new area and thus ended their existence as a nomadic people. ${ }^{43}$ Before the modern notion of a nation arose, people in exile did not feel deprived of a nation or state, but rather disconnected from their culture, within the notion of civilisation. Glissant remarks that Greek philosophers, such as Plato and Aristotle, regarded exile and voyaging as 'necessary for a being's complete fulfilment'. ${ }^{44}$

The idea of civilisation - Plato regarded the city as a centre of civilisation - was opposed to the non-civilised, opposed to the Other, the barbarian. During the traveling and conquering, emperors established empires and new cities, thus according to Glissant at that time roots were not yet important. The centre and the periphery were equal. ${ }^{45}$ However, when the idea of the nation arose in the Western world, the roots of culture became fixed in one place and intolerant towards other groups.

Unlike Welsch, Glissant discusses the importance of language in this process: 'The root is monolingual'. ${ }^{46}$ The individual in exile is not able to speak the own language and lacks the ability to communicate. Founding books such as the Bible are in fact books about errantry and the basis on which to propagate one's own roots. 'My root is the strongest'. ${ }^{47}$ Moreover, conquerors from the Western world exported their languages (French, English, Spanish, Portuguese, Dutch, Danish), which became 'vehicular' languages. They took the centre to the periphery. As we well know, some of these languages, such as English today, became international. According to Glissant, 'Relation is spoken multilingually'. ${ }^{8}$ Uprooting can be seen as enabling identity, and exile can be seen as beneficial, as Glissant states, but

41 Ibidem.

42 Glissant, Poetics of Relation, p. 12.

43 Ibidem.

44 Glissant, Poetics of Relation, p. 13.

45 Glissant, Poetics of Relation, p. 14.

46 Glissant, Poetics of Relation, p. 15.

47 Glissant, Poetics of Relation, p. 17.

48 Glissant, Poetics of Relation, p. 19. 
it has to be experienced as a search for the Other through a benign circular nomadism and not by a violent invasive nomadism.

After these reflections on nomadism as a fundamental first phase in the lives and being of humankind, through the development of the state in the nineteenth century (thus, in fact, a relatively recent phenomenon) to migration, which we could call a new form of nomadism - a form of movement that can be straightforward, from the old homeland to the new, or a circulating nomadism, where the periphery becomes the centre - we need to ask - whether or not we are concerned with crossing borders or migrating within a state - how we should define minorities, migrants, nomads and people in exile.

As the state is still the reality in global political negotiations, and the political state is still seen as representative of the people, whether or not they are of the same ethnicity and/or share the same culture, I have chosen to maintain the state as my point of departure. The existence of small communities is paradoxical evidence of the fact that state borders can change and inhabitants/nations change and build new states or autonomous areas.

\section{Definition of minority and migrant groups}

On the basis of the definitions above, from a historical, political and/or an institutional perspective, as well on the basis of the studies discussed, I propose the following working definition of minority and migrant groups, which includes five categories relevant to Europe:

1. Historical, ethnic and territorial minorities: the Sámi (the Lapps) and the Tornedalians in Scandinavia, and, if we apply the concept of geopolitical ties, the Inuit in Greenland, part of the Danish Monarchy. ${ }^{49}$ The Sámi and the Inuit are indigenous peoples.

2. National minorities: for example, the Danes in Northern Germany (Holstein), the Germans in Southern Denmark (Schleswig or Southern Jutland).

49 The term used in Canada and the US for the American Indians (excl. Inuit) is 'First Nations'. In 2013, the Metis, descendants of Indians and colonisers from Europe, also obtained the status of First Nations, although this remains controversial. See also: http://www.metisnation.ca/wp-content/uploads/2015/o8/PST-LLP-SummaryDaniels-Case-July-2015-Update.pdf (accessed October 15 2015). 
3. Migrants: historical, for example, the Germans in Sweden in the fifteenth century, the Walloons in the sixteenth century, the Chilean political refugees in the 1980s; ethnic minorities, for example, people from Morocco or Syria in the suburbs of the big cities of northwestern Europe. People in the first category might also be migrants as soon as they start to migrate across borders or within the state borders and leave their own cultural environment, such as the Sámi and the Tornedalians, who were originally migrants, moving from southeast Finland to the north in the fourteenth century. Minorities of the second category can also be migrants.

4. Minorities in the diaspora and in exile (e.g. refugees from the Balkans, the Jews, the Kurds). Within this category there is a differentiation between minorities who have lost their homeland (e.g. it no longer exists) and those who have a territory they regard as their homeland, but where they cannot live for political reasons.

5. Nomadic minorities (e.g. Roma). While Glissant would probably call them circulating nomads who want to get to know the Other, in reality they function as the Other in Western countries, in which the majority population does not want to establish any relationship.

These definitions of various categories of minorities and migrants reveal the historical complexity and dynamics of small communities. In the next section of my theoretical framing I will deal with the literature of minorities and the strategies of using literature and cultural transfer for self-expression.

\section{Language, literature, cultural transfer}

As Hroch mentioned, literature plays an important role in Phase A of nation-building. Actors such as scholars, writers and priests collect literary texts and other cultural products to demonstrate that the small community concerned has a literature in its own language. In their book, Kafka. Towards a Minor Literature, Deleuze and Guattari point out three characteristics of a minor literature, ${ }^{50}$ although they do not link these to a minor language as such. This idea can also be linked to Hroch's notion that

50 Gilles Deleuze and Felix Guattari, 'What is a Minor Literature?', in: Gilles Deleuze and Felix Guattari, Kafka. Towards a Minor Literature (Minneapolis/London, 1986), pp. 16-27. 
a majority language can be a minority language in a given geographical and political context. What may be defined as a minority literature is what a minority 'constructs within a major language'. ${ }^{11}$ According to Deleuze and Guattari, and this is the first characteristic they attribute to minor literature, language is influenced by deterritorialisation. As I will show below, this is not the case for all minority literatures. In the twentieth and twenty-first centuries, one of the important topics in minor literature written by authors belonging to what I have called historical, ethnic and territorial minorities - who lost their own language in the process of assimilation to the major culture, even if this took place in their own territory - is relearning the mother tongue. In this case, a reterritorialisation of language takes place.

The second characteristic defined by Deleuze and Guattari is the connection of the individual to politics. They argue that major literatures tend to be more connected to the individual than to the political sphere. Hippolyte Taine's idea that the author is influenced by environment, race and moment is adapted here. Minor literatures have limited space, according Deleuze and Guattari: 'its cramped space forces each individual intrigue to connect immediately to politics'. ${ }^{52}$ The individual thus serves a greater purpose. Thus, the family triangle is embedded in other triangles, such as commercial, economic, bureaucratic and juridical triangles. To these triangles I would like to add language, politics and ethnicity. One might also want to discuss whether politics is important for every minor or migrant writer. In Sweden, various migrant writers do not want to be categorised as such. The Swedish scholar Magnus Nilsson has even suggested that the category of the migrant writer in Sweden no longer exits. ${ }^{53}$ It is a mechanism that could be regarded as an aesthetic assimilation.

A logical third characteristic is the collective value of minor literature. Because of its limited space, there are few great authors, and thus the minority literature is dependent on the collective statement; its value and function lies in a 'collective, even revolutionary, enunciation'.${ }^{54}$ Again, one might wonder if this can be applied to every minority situation.

51 Deleuze and Guattari, 'What is a Minor Literature?', p. 16.

52 Deleuze and Guattari, 'What is a Minor Literature?', p. 17.

53 Magnus Nilsson, 'Literature in Multicultural and Multilingual Sweden: The Birth and Death of the Immigrant Writer', in: Wolfgang Behschnitt, Sarah De Mul, Liesbeth Minnaard, eds., Literature, Language, and Multiculturalism in Scandinavia and the Low Countries (Amsterdam, 2013), pp. 41-61.

54 Ibidem. 
Deleuze and Guattari offer an interesting bridge to a postcolonial perspective in their description of minority status as a revolutionary force. When a minority writer produces literature within the context of a major or established literature, he or she has to find their 'own patois', their 'own third world', and their 'own desert'. ${ }^{55}$ This enables us to define marginal literature. If we adapt Homi $\mathrm{K}$. Bhabha's concept of the 'third space', ${ }^{56}$ it is possible to map the phases of assimilation (mimicry) with the deterritorialisation of language, ambivalence (revolution?) towards shaping a collective, and the third possibility, of a minor literature that rediscovers its own language.

'Reterritorialisation' - understood in the sense that an author wants to rediscover a lost language, a close connection between the individual and politics, to make a collective statement, as well as demonstrating some ambivalence towards the major literature - requires decisions and strategic choices.

As mentioned above, many minority writers have lost their own language (or perhaps never learned it) and thus write in the major language. Others have insufficient skills to write in their own language. Nevertheless, minority writers have to make important decisions about their position as an individual and as a writer. This is described in detail by Iban Zaldua, a Basque writer, in his intriguing article, 'Eight Crucial Decisions (A Basque Writer is Obliged to Face)' ${ }^{57}$ I have formulated Zaldua's questions below:

1. The first is related to language: In which language is the author going to write? In the minority language or the dominant language? Zaldua mentions several possibilities: writing in the dominant language and then moving to one's own language, or writing first in one's own language and then moving to the dominant language, or even selftranslation. Zaldua does not mention that there are writers who cannot write in their own minority language and have to learn this first (writing skills are not usually sufficient).

2. The second is the position a writer wants to take within the institutions and their attitude regarding their own literature. There are three

55 Deleuze and Guattari, 'What is a Minor Literature?', p. 18.

56 Homi K. Bhabha, The Location of Culture (London/New York, 1994/2004), p. XX

57 Iban Zaldua, 'Eight Crucial Decisions (A Basque Writer is Obliged to Face)', in: Mari Jose Olaziregi, ed., Writers In Between Languages: Minority Literatures in the Global Scene (Reno, 2009), pp. 89-112. 
positions: 'pathetic speakers' (who are pessimistic about the future of the language), 'sympathizers' (who do not speak the language) and 'non-sympathizers' (who reject the language). Zaldua claims that writers are usually pathetic speakers and argues for more open critique and debate, and even cultural irony. ${ }^{58}$

3. The third decision is whether or not to become a nationalist. This is, of course, an important issue in the Basque region, but this decision may also be relevant to minority writers in Nordic countries. I will come back to this later. Zaldua states that race and religion were important in the first nationalist movements. With the ETA movement that started in the 1950s, the Basque language became a basic element of Basque identity. ${ }^{59}$ According to Zaldua and others, language and nationalism should not be so closely tied together as they are now. Although things have changed in the last decade, Basque nationalism is still reflected in Basque literature.

4. The fourth decision a Basque writer has to face is whether or not to write about 'The Thing', Zaldua's name for the Basque conflict, which reveals its traumatic character. Some authors regard writing about such events as an opportunity to add something new to European literature and to gain visibility 'in the global literary market'. However, this kind of committed literature should not be regarded as a political manifesto or as approving of terrorism.

5. The fifth decision is whether or not to bypass Spanish when a writer wants to conquer the literary world, and here we are entering the field of cultural transfer. For political reasons, some writers ignore Spanish and translate their works, or have them translated, into French or English. However, there are also other views: 'Our literature must first be known in our country, if anywhere. In the end, Basque literature has been written for Basques to read. The basis for a living and healthy literature is strongly linked with language and culture. To be known abroad comes later'. ${ }^{60}$ Zaldua made the choice to also write in Spanish - the Spanish readers are neighbours after all.

6. The sixth decision concerns the fact that Basque writers have to rely on their own literary tradition, but that tradition, in this instance, was

58 Iban Zaldua, 'Eight Crucial Decisions', p. 93.

59 Iban Zaldua, 'Eight Crucial Decisions', p. 94.

60 Iban Zaldua, 'Eight Crucial Decisions', p. 100. 
poor and started as late as the 1960s. This resulted in the need to invent a tradition. Zaldua makes the ironic comment that we now know that Shakespeare merely rewrote the works of a Basque.

7. A writer must also decide whether to be an ironical writer or not. Zaldua calls irony 'a witty form of literature free from dogmatism'.${ }^{61}$ In Basque literature there are various kinds of plots, such as the tragic (the lost battle plot) or the naive plot (a kind of escapism in literature). One problem with irony is that it is in fact the reader who must understand the intention of the author. Zaldua believes that the dramatic (tragic) plot or the 'naive' plot are more effective than the ironic. Irony also requires self-irony, but are minorities able to laugh at themselves?

8. The last decision is what you want to achieve at conferences: Do you want to bring the literature to the attention of others or to make yourself known as a universal writer? In choosing the native line, in talking about the few speakers of the language, reflecting a sort of exoticism, Zaldua himself takes a practical position. He sees language as an instrument and regards both Basque and Spanish as his literary languages. Moreover, he does not believe in the concept of 'universal literature', which is very much oriented to the West.

In addition to the decisions a minority writer has to face, the keyword in Zaldua's text is 'language'. When taking positions in the literary field it is clear that the attitude towards language is important.

With respect to the first decision, whether to write in the minority language or in the dominant language, it is possible to delineate three levels. Firstly, one has to consider whether a writer belonging to a minority has the skills to speak and/or to write in the minority language. This is an individual act and decision. Secondly, there is decision at an institutional level. What position will the writer take within the institutions? Are they active or passive? Thirdly, there is the supra-territorial level, concerning the position of the minority writer as a cultural transmitter and the possibility of entering the national and international literary fields.

Decisions five and eight deal with this issue of cultural transfer. Cultural transfer can be used in the process of defining or redefining identity. Many minority writers act as cultural transmitters, literary historians and critics. The profile and position of the writer/transmitter, both in the area of

61 Iban Zaldua, 'Eight Crucial Decisions', p. 105. 
transmission and in the literary system of their own minority culture, as well as the receiving major culture, need to be discussed. Cultural transfer can be considered an important instrument for minority communities and for language survival. Instruments such as literary histories, multilingual children's books, small publishing houses and the use of the internet are essential for the survival of a minority language.

\section{Examples of the kinds of decisions that authors make}

Here, I will briefly discuss four minority and migrant authors against the backdrop of my working definition of minority communities, the nationoriented thinking as explored by Hroch and Zaldua's decisions as discussed above.

The authors Mikael Niemi and Bengt Pohjanen belong to the Tornedal Finns, a historical minority in the north of Sweden. Meänkieli, which means 'our language', was recognised as an official minority language in Sweden in 2000. Both authors were and are active in promoting the Torne Valley area and its culture but in very different ways, taking very different positions.

Mikael Niemi made his breakthrough with Populärmusik från Vittula (Popular Music from Vittula, 200o), a novel written in Swedish that made the Torne Valley visible to the rest of Sweden, as well other countries. The novel was also translated into many languages, including minority languages. Niemi cannot be regarded as a pathetic speaker, although he is quite pessimistic about the survival of Meänkieli. Niemi is an author who decided to be realistic and pragmatic; he was one of the advocates of theatre in Meänkieli, wrote his novels in Swedish and entered the global literary market with the success of Popular Music from Vittula. He decided to take an ironic approach in making his own region and his own literary work visible. He cannot be regarded as a nationalistic author.

Bengt Pohjanen made other decisions. He is a multilingual writer, publishing in Swedish, Finnish and Meänkieli. He is also very active within the institutions, having established a foundation, one of the activities of which is the awarding of a literary prize for minority literature. He is also active as a translator. His novels have a more satirical than ironic tone. Pohjanen is a language activist and Zaldua would call him a pathetic speaker.

Pohjanen has also co-written literary histories with Kirsti Johansson: Den tornedalsfinska litteraturen I. Från Kexi till Liksom (2007) and Den tornedalsfinska litteraturen II. Från Kalkkimaa till Hilja Byström (2009). 
Anne Heith has written about this new literary history in this volume so I will not go any further into this except to mention that the second volume begins with a chapter entitled: 'Vår identitet är i språket' (Our identity lies in the language).$^{62}$ Here we encounter the revival of a romantic nationbuilding perspective à la Hroch. In my opinion, Pohjanen conceives of himself as a typical intellectual from Hroch's Phase A. He collects literary texts, writes literary history and uses phrases such as 'even if we do not (yet) have our own state, we are a nation with our own language'. ${ }^{63}$ Following Deleuze and Guattari, Bengt Pohjanen could be called a typical political writer, but not one concerned with deterritorialisation. On the contrary, Pohjanen can be regarded as a transcultural writer, using various languages, and with a homeland he denotes as a nation without a state.

Two examples of writers belonging to a historical, ethnic and territorial minority category are Ann-Hélen Laestadius and Annica Wennström, both of whom write about young Sámi girls and women who are searching for identity. They do not speak the Sámi language because their mothers did not teach them or could no longer speak the mother tongue themselves. Here, I will briefly discuss Laestadius and compare her decisions and positions with those of the writer Alejandro Leiva Wenger.

Ann-Helén Laestadius was born in Kiruna in 1971, leaving her home town in 1999 to work in Stockholm as a crime reporter. She could not write in the Sámi language, but published her first work in Swedish in 2007, Sms från Soppero (Sms from Soppero), followed by Hej vacker (Hello Cutie, 2010), Ingen annan är som du (Nobody is Like You, 2011) and Hitta hem (Coming Home, 2012). Her books are about young Sámi people today, demonstrating the importance of Sámi language and presenting Sámi culture in a positive way. They tell the story of assimilation and the denial of Sámi roots. Her books for adolescent readers were also well received by adults, especially those with the same background: many children born in the 1960 s and 1970 did not learn Sámi and thus lost a part of their identity.

Laestadius's books are also autobiographical. Her mother belonged to the Sámi and had to attend a 'nomad school' and become Swedish.

62 Bengt Pohjanen, 'Vår identitet är i språket', in: Bengt Pohjanen and Kirsti Johansson, eds., Den tornedalsfinska litteraturen II. Från Kalkkimaa till Hilja Byström (2009), pp. 9-14.

63 'Fast vi inte har en egen stat (ännu) är vi ett folk, som har ett eget språk' (transl. from Swedish by PB), Pohjanen, 'Vår identitet är i språket', p. 13. 
She was brought up to be ashamed of belonging to the Sámi people and speaking the language and so she did not speak Sámi with her children. Laestadius thus grew up with the notion that one should not be or feel Sámi, but nevertheless harboured the dream of becoming a real Sámi. Her mother's trauma and her own search for identity and an understanding of her mother tongue are the points of departure for her books.

Laestadius started learning Sámi at university and noticed that there were many Sámi people who were in the same situation, having lost their knowledge of their mother tongue. Writing about her own search and her struggle to learn Sámi gave her a sense of pride and a feeling of being part of a collectivity once again - part of a people with a history. To be able to speak Sámi is important for her sense of identity. She writes her books in Swedish but includes Sámi words and phrases. The stories, in fact, contain a mix of languages: Swedish, Sámi and sometimes Finnish or Meänkieli. Language also seems to be a marker of identity: 'And maybe identities, Agnes thought. She could tell that their grandparents sounded different when they talked in Sámi' ${ }^{64}$

To be able to speak Sámi is to be able to speak from your heart, a feeling that Vuokko Hirvonen also describes in the study Voices from Sápmi. Sámi Women's Path to Authorship (2008). ${ }^{65}$ Hirvonen defined four generations of women writers in Sámi literary history: 1. Great-grandmothers, born in the late 180os, 2. Grandmothers, born between 1900 and 1939, 3. Mothers, born between 1940 and 1960 and 4. Daughters, born after 1960 (Laestadius). For all of the generations, the literature is connected with ethno-politics, a struggle to regain esteem and the right to keep and use their own language. However, Laestadius's mother, and also Laestadius herself as a teenager, denied their Sámi roots, so she cannot be called a 'daughter' according Hirvonen's definition. Perhaps we should call Laestadius a lost daughter who had to learn the language and accept her Sámi identity.

Alejandro Leiva Wenger, born in 1976 in Concepción, Chile, migrated with his mother and brother from Chile to Stockholm when he was nine years old. Although Laestadius and Leiva Wenger are from different cultures, some themes in their work are the same: language and ethnicity. Does this mean that the concepts of 'minority' and 'migrant' are interchangeable?

64 Laestadius, Ingen annan är som du (Nobody is Like You), p. 84.

65 Vuokko Hirvonen, Voices from Sápmi. Sámi Women's Path to Authorship (1998, 2008). 
Leiva Wenger was the first writer in Sweden to use the migrant language, known as 'Rinkebyswedish', which is a street language, a mix of Swedish, Spanish, Finnish, Arabic, Turkish, Kurdish, Greek, Persian and English loanwords. His first work was published in 2001, a collection of short stories called Till vår ära (In Our Honour). While in some of these stories he does not use street language, the theme is the homeland. Others are very much influenced by hip hop music, especially the Swedish band The Latin Kings. In other stories, for example in 'Borta i tankar' (Lost in Thoughts), he uses a mix of languages connected to identity, class and ethnicity. Leiva Wenger received very good reviews, with positive comments about a migrant writer who was finally using the migrant language.

The breakthrough of new migrant literature actually came with Jonas Hassen Khemeri's Ett öga rött (One Eye Red) in 2003. Interestingly, both Leiva Wenger and Hassen Khemeri actually use an artificial migrant language. According to Magnus Nilsson, migrant literature in Sweden has deconstructed itself; there is a denial of the label 'migrant literature'. After his first book, Leiva Wenger became active as a playwright. In 2011, he wrote 127 (a monologue) and in 2013, Författarna (The Authors), both of which are about integration and racism. Leiva Wenger does not want to be regarded as a 'migrant writer', a position he shares with many of his colleagues who are second-generation migrants. Nevertheless, their literature deals with language and identity, racism and integration.

When we compare the two authors we can observe some similarities but also some differences. Laestadius rejected her Sámi identity in the beginning, but as a writer she now embraces it and promotes literature in Sámi. She lost her language and wants it back. Leiva Wenger did not want to be regarded as a migrant writer, and stopped writing for a time, returning with plays about racism in Swedish society. As a child he had to learn another language, and perhaps we can see his reluctance to be labelled a migrant writer as reflecting a desire for a more hybrid identity. Nevertheless, language, identity and ethnicity are essential topics in the works of both writers. Their differences lie in the positions they have taken and the decisions they have made.

\section{Overview of contributions}

This volume comprises four parts, each containing two articles. The first part 'Borders/Nation/Language: the case of Denmark and Germany' begins with a contribution by Nikolaj Bijleveld. In 'Germans Making Danes: 
Germans and the German Language in Copenhagen and the Construction of Danish Culture, 1750-1880', Bijleveld discusses how Copenhagen lost its multicultural and international character in the nineteenth century, using various studies on nationalism, ethnolinguistic nationalism and literary history as his theoretical framework. There was a plurality of cultures and languages in eighteenth-century Copenhagen, and a large German minority, for example. Paradoxically enough, the process of cultural transfer was one cause of the cultural change in Copenhagen. German philosophers and authors imported ideas on language and nationality that led to the development of a national identity in which the Danish language became the single language. In this sense, German ideas transformed the Danes with their international outlook into 'real' Danes.

In 'Language as cultural metaphor: the creation of a national identity in the German-Danish border area', Andrea Graw-Teebken discusses whether language was an important factor in ideas on national identity in Schleswig, the 'Danish' part of Schleswig-Holstein. An analysis of documents written in the period 1830 to 1880 by bureaucrats and politicians from this border region reveals that from around 1850 the idea of language as an important medium for national 'awakening' was quickly gaining traction. This correlates with Bijleveld's observations. The document analysis makes it clear that the border between Denmark and Germany was problematic. Graw-Teebken defines a 'border area' as an area 'where there are intersections of a cultural, linguistic or political nature'. Is the border determined by language or is it a natural, geographical border? GrawTeebken uses classic historical source analysis to reach the conclusion that national identity is based on an illusion of homogeneity. It is particularly in border areas that the ambivalence and variability of options for national identification, such as language, come clearly to the forefront.

The second part of the volume is entitled 'Cultural Transfer, Language Frontiers, Across Borders'. In 'The Discovery of Finland - Patterns in Cultural Transfer', Adriaan van der Hoeven examines changing attitudes towards the Finnish and Swedish languages in nineteenth-century and turn-of-the-century Finland, studying the effect this had on the reception of Finnish culture and literature in the Dutch-speaking area. Van der Hoeven uses Hroch's phases and A.D. Smith's conclusions to describe the process of national awakening. Finland was discovered by the Dutchspeaking regions through foreign sources at the start of the nineteenth century. The first direct translations from Finnish appeared after 1850; one of the most important was the translation of the Finnish national 
epic Kalevala. The political situation in Finland gained more attention in the period 1880-1900, with Finland, since 1809 a grand duchy of Russia, increasingly confronted with Russification. After Finnish independence in 1917, the number of translations increased, but the translated literature no longer reflected the Finnish canon. The picture became more varied, and in the first half of the twentieth century mainly popular novels were translated. Sally Salminen's novel Katrina (1936) is a good example of this.

Salminen's novel takes centre stage in Roger Holmström's contribution 'Against all odds. Sally Salminen's Katrina and the possibilities of cultural transfer'. Katrina was translated into many languages, including Dutch. Holmström describes how cultural transfer made an international success of a debut novel from the periphery. Holmström also relates this to the question of whether or not international bestseller status justifies a place in the Fenno-Swedish canon. Holmström sets 'Sally's fairy tale' against the backdrop of the linguo-political situation in Finland. With Fenno-Swedish literature likely to be relegated to marginal status in the 1930s, Salminen's success came at just the right time. Salminen combines ethnographic description with eco-criticism and universality. Holmström argues that the plot and language, which conjure up associations with the Icelandic sagas, had a significant influence on its worldwide success. He goes on to claim that the book's successful cultural transfer was due to its ethnographic content and the universal portrait of the female main character. The novel describes a form of farming life that has vanished, but a life in which modern people can recognise general human phenomena.

The third part of the volume, 'Minor Languages and Literary History/ Within Borders', includes two case studies about minority languages within state borders. In 'The rise, dispersal and stabilisation of New Norwegian literature', Idar Stegane describes how New Norwegian came into being in the nineteenth century together with the role of literature written in New Norwegian, the second language in Norway. The aim of this article is to show that New Norwegian can be considered a counter-hegemonic cultural movement. Stegane discusses some nineteenth-century 'pioneers' and key twentieth-century figures, institutions and genres. The first nineteenth-century pioneer was a farmer's son, Ivar Aasen (1813-1896), whose achievements included the creation of a new language based on Norwegian dialects. Other pioneers were Aasmund Vinje, who wrote literary criticism in New Norwegian, Arne Garborg, who was to develop literary New Norwegian to the full, and his wife Hulda Garborg, who wrote plays in New Norwegian. Stegane places his study of the development of 
New Norwegian in a Habermasian tradition that claims that the growth of a culture can only be understood by studying less formal institutions. A New Norwegian literary field was created in Norway, although this was not without some conflict with what is known as the Bokmål literary field.

The Faroe Islands are an autonomous region within the Kingdom of Denmark, but due to their geographical location they have more of a virtual position within the borders of the country, in contrast to New Norwegian. As in other Scandinavian countries, there are two languages, one of which - Danish - from the fifteenth century onwards, was for a long time the only official and written language.

In 'Towards a Monolingual Canon - Faroese and Danish on the Faroe Islands', Malan Marnersdóttir describes the change in status of these two languages. After the implementation of home rule in 1948, Faroese became the first language and Danish the second. Language became an important tool in the construction of a national identity and a literary canon. Marnersdóttir uses postcolonial theories and the term 'mimicry' to demonstrate the ambivalence and complexity of the situation on the Faroe Islands. The rejection of Danish meant that Faroese writers who wrote in Danish were only included in the Faroese canon in 1975 once their work had been translated into Faroese. Danish literature was excluded from the canon. This exclusion process is reminiscent of developments in Copenhagen as described by Bijleveld. However, Marnersdóttir suggests that crossing linguistic frontiers, also by means of cultural transfer, was of essential importance to the emergence of Faroese literature and that it caused new 'hybrid' forms and ideas to arise. This complicated the selection process for a Faroese literary history, the first volume of which was published in 2011.

The last part of this volume, 'Literary History/Within Borders/Without Borders', starts with Anne Heith's 'Reconstructing National Archives Ethnonational Mobilisation in Meänmaa'. Heith explores the concept of the nation in her analysis of the discourse in Den tornedalsfinska litteraturen. Från Kexi to Liksom (Tornedalian Literary History: From Kexi to Liksom, 2007). This literary history by Bengt Pohjanen and Kirsti Johansson is the first to be written in Meänkieli, the language spoken in the Torne Valley. Heith takes Homi K. Bhabha's postcolonial studies approach, which focuses on the problem of how to narrate the nation in the context of 'top-down' narration by state institutions and the discourse of minorities. Heith demonstrates that Pohjanen and Johansson's literary history is a 'performative deconstruction of a Swedish homogenising discourse of the 
modern nation-state'. She also compares the experience of the Sámi with the cultural mobilisation of the Tornedalians, emphasising the importance of cultural archives and Foucault's arguments about establishing hierarchies. National literary histories have been used as instruments to strengthen the national identity of nation-states, and allow no space for linguistic or other minorities. This can also apply to internal colonisation. Writers such as Pohjanen and Mikael Niemi have shown that there was cultural mobilisation in the Swedish Torne Valley.

The final contribution, 'Cultural Transmission. Diaspora Writing from the Balkans', by Elka Agoston-Nikolova, is about how to include authors in cultural transfer studies who transcend borders and write in the new environment. Do these writers express other experiences of individual, national or cultural identity? Agoston-Nikolova discusses the history of emigration from the Balkans - historically a geopolitical region with multicultural and multilingual communities - and defines three waves: first, the establishment of Communist regimes; second, the fall of Communism and the conflict in the Balkans in the 1990s; and third, what Agoston-Nikolova calls the wave of the intellectual nomad, who moves abroad and starts writing in a new language or more than one language. Agoston-Nikolova states that the literature of the third wave is neither that of the exile nor part of a national canon but a 'creative, experimental, self-reflexive individual writing which transcends national borders', a transnational literature. This is also expressed in the language. AgostonNikolova illustrates this with the beautiful poem Ein unbekanntes Wort from 2008 by Tzveta Sofronieva. The poem is written in a mix of Bulgarian, English and German. The Bulgarian words, the 'unknown' words, stand for a metonymic gap, and the writer uses them to remind us of the mother tongue. Mixing languages and cultures is nothing special for young, global readers. Agoston-Nikolova believes that this new development requires new approaches to cultural transfer and cultural translation.

In conclusion, this introduction has redefined the concepts of minority and migrant groups against a background of the historical and institutional dimensions and we have seen the different positions that minority and migrant groups can take. Concepts such as state, homeland, transculturality, migration and nomadism were also discussed. In the second part, I demonstrated how literature and cultural transfer have been used as important tools in expressing identity. This survey made it possible to present a new perspective on minority and migrant groups. As examples, I presented four writers belonging to various minority and migrant groups: 
Mikael Niemi, Bengt Pohjanen, Ann Hélen Laestadius and Alejandro Leiva Wenger. In this light, in combination with the eight contributions to this volume, a new topic has become apparent: the differences between the various categories of minorities and the importance of literature and cultural transfer for minorities as well as for migrant groups. This will be an issue for further investigation in the future. 